\title{
Chancellor Allen and the Fundamental Question
}

\author{
D. Gordon Smith
}

\section{INTRODUCTION}

There is little doubt about the extent of Chancellor Allen's judicial reputation, both among legal scholars and practicing attorneys. Toward the end of Chancellor Allen's judicial career, Professor Michael Dooley offered the following assessment: "He is widely regarded by the bar and academics as the leading judicial expert on corporate and business law cases." 1 Professor James Cox, who claims that he often disagrees with Chancellor Allen, was more effusive: "He's really an extraordinary judge. He brings the acuity of years of practice as well as a very outstanding academic bent-which is something characteristic of the very best judges in American jurisprudence."2 Practitioners Dennis Block, Stephen Radin, and Michael Maimone gave the following tribute: "Many lawyers, academics, and jurists have 'struggle[d] to fashion answers' to the myriad of business judgment rule questions raised during the 'deal decade' of the 1980s and the new issues that have arisen in the $1990 \mathrm{~s}$, but none has surpassed the intellectual ability and skill consistently demonstrated by Chancellor William T. Allen...."3 Commentators engage in

- Associate Professor of Law, Northwestern School of Law of Lewis \& Clark College <dgsmith@lclark.edu>. Special thanks to Larry Hamermesh, who acted as a sounding board and provided useful comments on a draft of this Article. Thanks also to Ron Gilson, who willingly shared his admiration for Chancellor Allen and confirmed many of my own views. Ken Piumarta supplied excellent research assistance.

1. Stephen Keating, Chancery Court: Unique, 'Schizoid', DENV. POST, Mar. 15, 1996, at C1 (quoting Professor Dooley).

2. Joyce M. Rosenberg, Judge in Time-Paramount Fight: Highly Regarded but Hard to Predict, AssOC. PRESS, July 9, 1989, at 1, available in 1989 WL 4045619.

3. Dennis J. Block et al., Chancellor Allen, The Business Judgment Rule, and the Shareholders' Right to Decide, 17 DEL. J. CORP. L. 785, 785 (1992). 
occasional sniping against particular Allen decisions, ${ }^{4}$ but the general estimation of his abilities is overwhelmingly positive. ${ }^{5}$

Although judicial reputations are inevitably contingent, ${ }^{6}$ there is a wide gulf between "celebrity" and greatness. Judge Ito is a celebrity; Chancellor Allen was a great judge. But Chancellor Allen's substantial reputation is anomalous. Large judicial reputations are usually made by Supreme Court justices or an occasional federal appellate court judge, like Learned Hand or Henry Friendly. After all, these judges are in a position to craft enduring change. ${ }^{7}$ As Margaret Sachs notes, "Transient changes-such as those quickly trumped by Congress or the Supreme Court-are apt soon to be forgotten, along with the judges who brought them about. Enduring changes-and the judges who brought them about-are likely to be remembered." 8 Unlike most renowned judges, Chancellor Allen was a state trial court judge!

Of course, the Delaware Court of Chancery is not a typical state trial court. Stephen Massey noted that Chancellor Allen's reputation is partially attributable to the fact that "he has presided over the Delaware Court of Chancery, the nation's central forum for shaping American corporate law, during a period of intense corporate activity." Especially during the late 1980s and early 1990s, when Chancellor Allen was deciding cases, the Delaware Court of Chancery was the center of the corporate law universe. Allen was Chancellor and could assign the most important cases to himself. ${ }^{10}$ Lynn Stout has likened the position of Chancellor to the position of Chief Justice of the United States Supreme Court. ${ }^{11}$

4. See, e.g., John Riley, The Good, Bad and Ugly: A Few Arbitrary Awards, NEWSDAY, Dec. 26, 1989, at 2 (giving Allen the "Corporate Stalinism" award for his opinion in Paramount Communications Inc., v. Time Inc., CIV. A. Nos. 10866, 10670, 10935, 1989 WL 79880 (Del. Ch. Jul. 14, 1989), which Riley called "the legal equivalent of Manuel Noriega for the notion of corporate democracy");

5. For other statements about Chancellor Allen's status as a judge, see, e.g., Stephen J. Massey, Chancellor Allen's Jurisprudence and the Theory of Corporate Law, 17 DEL. J. CORP. L. 683, 684 (1992) ("Chancellor William T. Allen ... is one of the most significant contemporary jurists.").

6. Margaret V. Sachs, Judge Friendly and the Law of Securities Regulation: The Creation of a Judicial Reputation, 50 SMU L. REV. 777, 779 (1997). But see RICHARD A. POSNER, CARDOZO: A STUDY IN REPUTATION 63-64 (1990).

7. Sachs, supra note 6 , at 783-84.

8. Id. at 783-84 (citations omitted).

9. Massey, supra note 5 , at 686 .

10. The Delaware Court of Chancery is comprised of five judges: one Chancellor and four Vice Chancellors. The Chancellor is the "chief judge" of the court and handles numerous administrative functions for the court, including the assignment of cases.

11. Firms Watch Change at Top of Del. Court, BALT. SUN, Mar. 3, 1997, at 10C (quoting Professor Stout). 
Business developments during the 1980s required guidance from the nation's guardians of corporate law-the Delaware judiciary - and Chancellor Allen was there to provide it. Richard Posner has observed, "Given two ... judges ... of equal quality, one may be more influential than another simply because he is working at a time ... [when] standards . . . are more fluid than at other times. . .."12 This insight actually increases the puzzle of Chancellor Allen's reputation, because he was not a great innovator. ${ }^{13}$ Few of his cases appear in law school casebooks, ${ }^{14}$ and some his most-cited opinions were in cases where the Delaware Supreme Court had the last word..$^{15}$ Chancellor Allen's conservative inclinations might have dampened his chances for judicial fame because, as Margaret Sachs argues: "In general, activist judges have greater opportunities for renown than do judges who curtail past excesses. The activist receives credit for the doctrines she creates, whereas the curtailer at most shares credit with the authors of the doctrines he pares back." 16

So why is Chancellor Allen considered to have been a great judge? Any effort to explain judicial reputation inevitably treads on soggy

12. POSNER, supra note 6 , at 71 .

13. As with most generalizatons, this one has exceptions. See, e.g., In re Caremark International Inc. Derivative Litigation, CIV. A. No. 13670, 1996 WL 549894, at *11 (Del. Ch. Sept. 25,1996 ) (finding within the duty of care "a duty to attempt in good faith to assure that a corporate information and reporting system, which the board concludes is adequate, exists"); Credit Lyonnais Bank Nederland, N.V. v. Pathe Communications Corp., CIV. A. No. 12, 150. 1991 WL 277613, at *34 (Del. Ch. Dec. 30, 1991) (concluding that "where a corporation is operating in the vicinity of insolvency, a board of directors is not merely the agent of the residue risk bearers, but owes its duty to the corporate enterprise.").

14. A survey of three major casebooks reveals very little use of Chancellor Allen's opinions. See ROBERT W. HAMILTON, CORPORATIONS INCLUDING PARTNERSHIPS AND LIMITED PARTNERSHIPS: CASES AND MATERIALS (5th ed. 1994) (referring to decisions in Cinerama, Inc. v. Technicolor, Inc., 663 A.2d 1134 (Del. Ch. Oct. 12, 1994) and Paramount Communications Inc. v. Time Inc., CIV. A. Nos. 10866, 10670, 10935, 1989 WL 79880 (Del. Ch. Jul. 14, 1989) (in the notes); JESSE H. CHOPER ET AL., CASES AND MATERIALS ON CORPORATIONS (4th ed. 1995) (including excerpts from five cases: Mendel v. Carroll, 651 A.2d 297 (Del. Ch. Jun. 17, 1994); Credit Lyonnais Bank Nederland, N.V. v. Pathe Communications Corp., CIV. A. No. 12150, 1991 WL 277613 (Del. Ch. Dec. 30, 1991); Paramount Communications, Inc. v. Time Inc., CIV. A. Nos. 10866, 10670, 10935, 1989 WL 79880 (Del. Ch. Jul. 14, 1989); AC Acquisitions Corp. v. Anderson, Clayton \& Co., 519 A.2d 103 (Del. Ch. Sept. 18, 1986); and Lacos Land Group v. Arden Group, Inc., 517 A.2d 271 (Del. Ch. Jul. 31, 1986)); William L. CARY \& MELVIN ARON EISENBERG, CORPORATIONS: CASES AND MATERIALS (7th ed. 1995) (including an excerpt from Cinerama, Inc. v. Technicolor, Inc., 663 A.2d 1134 (Del. Ch. Oct. 12, 1994), and a note on Blasius Industries, Inc. v. Atlas Corp., 564 A.2d 651 (Del. Ch. Jul. 25. 1988).

15. See, e.g., Cinerama, Inc. v. Technicolor, Inc., 663 A.2d 1134 (Del. 1994); Paramount Communications Inc. v. Time Inc., 571 A.2d 1140 (Del. 1990).

16. Sachs, supra note 6 , at 783 . 
ground: Attempts to quantify judicial reputation are often silly, ${ }^{17}$ and comparisons among judges are usually biased by personal or political motivations. ${ }^{18}$ Even if everyone agreed with Stephen Massey that "Allen's significance is more than a question of a judge who was in the right place at the right time," ${ }^{19}$ the task of explaining that significance would remain.

In this Article, I attempt to explain Chancellor Allen's expansive reputation by examining his ability to speak to what philosopher John Danley calls "the fundamental question": "What is the appropriate role of the modern corporation in a free society?" 20 From the chartering of the first corporations in the United States to the present day, debate over the fundamental question has been rancorous. On one side of the debate stand those who believe that society is best served when corporations strive to maximize profits for the benefit of shareholders; on the other side stand those who believe that corporations should have some more explicit public purpose.

17. James Gordon mocks Judge Richard Posner's attempt to "reduce [Cardozo's] achievements to a set of numbers on a baseball card" and argues that any attempt to understand judicial reputation in quantitative terms is an "effort to quantify the unquantifiable." James D. Gordon, III, Cardozo's Baseball Card, 44 STAN. L. REV. 899, 900, 902 (1992). Surveys may offer a more useful method of measuring judicial reputation, see, e.g., WILLIAM D. PEDERSON AND Norman W. Provizer, GREAT JUSTICES OF THE U.S. SUPREME COURT: RATINGS AND CASES (1993), but these are also problematic. See William G. Ross, The Ratings Game: Factors That Influence Judicial Reputation, 79 MARQ. L. REV. 401, 402 (1996) (stating that ratings of Supreme Court justices "may sometimes seem like a parlor game").

18. See, e.g., G. Edward White, The Canonization of Holmes and Brandeis: Epistemology and Judicial Reputations, 70 N.Y.U. L. REV. 576, 578 (1995) ("The further I probed into the process by which Holmes and Brandeis were canonized, the more I became convinced that the investment their acolytes made in them transcended their status as judges.").

19. Massey, supra note 5, at 687 . Massey elaborates on his statement as follows: In many important areas of corporate law-the rights of bondholders, the rise of institutional investors, the scope of a corporation's "constituencies"-Allen's opinions have responded to significant developments in corporate law and practice and have themselves established an agenda of corporate issues for the 1990s. Id. Massey contends, therefore, that Allen's reputation is justified by his ability to set the agenda for the development of corporate law and to do so in a way that "has contributed to the revival of interest in the study of corporate law as an intellectual endeavor." Id. at 687-88. Massey proceeds to study Allen's jurisprudence and concludes that it reflects two underlying themes: certainty (the ability of corporate planners to predict how the courts will analyze their transactions) and legitimacy (justification for allowing directors to exert power). Id. at 688 .

20. JOHN R. DANLEy, THE ROLE OF THE MODERn CORPORATION IN A FREe SOCIETY 2 (1994). William Ross identifies "Impact on Legal Development: The Vision Factor" as "the most fair and rational factor-and perhaps the most important element-that influences judicial reputation." Ross, supra note 16, at 404. Other factors identified by Ross include longevity of tenure (the "Geriatric Factor"), intellectual ability (the "Egghead Factor"), precourt and postcourt careers (the "Celebrity Factor"), and proximity in time (the "Myopia Factor"). 
Chancellor Allen's approach to the fundamental question - and his most important legacy to corporate law-was to embrace traditional corporate norms, not to create new norms, during an era of great upheaval and innovation in business practices. According to Chancellor Allen, determining the appropriate role of the modern corporation in a free society requires judicial intervention only on rare occasions. In most instances, directors and shareholders, operating within the constraints imposed by corporations statutes and other regulations (e.g., environmental law, labor and employment laws, antitrust laws, etc.), are best left alone.

But does this qualify Chancellor Allen as a great judge? Certainly his skill at explaining the application of traditional norms to new situations marks him as a judicial craftsman of high intellect. Nevertheless, I believe that his courage in facing down a Supreme Court intent of creating its own legacy ${ }^{21}$-all the while under strict public scrutiny ${ }^{22}$-is a mark of greatness. Admittedly, his approach was somewhat unoriginal (relying, as it did, on traditional standards), and it might be argued that it evaded the fundamental question because it was essentially procedural, not substantive. But Chancellor Allen understood that process often determines substance; the person who makes decisions often determines what the decisions will be. $\mathrm{He}$ also understood that society has a huge stake in the resolution of the fundamental question. In the words of Ron Gilson, "[a]s a matter of corporate law, the challenge was to apportion decision responsibilities among directors, shareholders, and courts. As a matter of social policy, the outcome would determine who governed the largest and most powerful private institutions in our society." ${ }^{23}$

21. Ronald Gilson makes a similar point, arguing that Allen's skill as a judge is evidenced by his ability to keep "the Supreme Court at bay so that a coherent body of law could be developed and maintained." Ronald J. Gilson, The Fine Art of Judging: William T. Allen, 2 DEL. J. CORP. L. $914-16$ (1997).

22. It is useful to remember that at the time Chancellor Allen took the bench in 1985 (and even today, to some extent), the Delaware courts were viewed as suspiciously promanagement by many scholars and in the popular press. See, e.g., Deal Reached in Revlon Case, SEATTLE TIMES, Dec. 3, 1985, at F10. Chancellor Allen's defense of traditional corporate norms, therefore, was not a strategic ploy designed to win him widespread praise.

23. Gilson, supra note 21, at 914-15. John R. Danley identified two normative "ideologies" relating to the fundamental question. The first ideology, which he calls the "Classical" view, holds that "the primary responsibility of corporations is to compete economically in the context of a limited government. For many, if not most, this means that the primary responsibility is to increase profits for stockholders; true believers would claim that the sole responsibility is to maximize profit for stockholders." DANLEY, supra note 20, at 3. The second is the "Managerial" ideology, which holds that "corporations have responsibilities to a wide variety of 'stakeholders' (employees, suppliers, distributors, competitors, consumers, local communities, governmental agencies, etc.) whose interests must be weighed in making a decision." DANLEY, supra note 20 , 
Nowhere in corporate law is the fundamental question more conspicuous or more relevant than in takeover cases implicating the shareholder primacy norm. ${ }^{24}$ When a board of directors has elected to sell control of a corporation, Delaware courts evaluate the behavior of the directors pursuant to standards announced in Revlon, Inc. v. MacAndrews $\& 5$ Forbes Holdings, Inc. (Revlon). ${ }^{25}$ When it applies, Revlon requires the directors to obtain "the highest price for the benefit of the stockholders." 26

Chancellor Allen began his judicial tenure shortly before the Delaware Supreme Court decided Revlon, and Allen's first opinion citing Revlon appeared less than one month after the Delaware Supreme Court's opinion was issued. ${ }^{27}$ Allen's final Revlon opinion was written shortly before he left the bench. ${ }^{28}$ In the 11 years between his first and last opinions dealing with Revlon, Chancellor Allen had both the opportunity and the inclination to speak often and forcefully on the fundamental question. ${ }^{29}$

The following sections analyze Allen's decisions involving Revlon duties and reveal his role in shaping those duties. Part one briefly describes the major cases decided by the Delaware Supreme Court defining the contours of "Revlon duties." Part two describes Chancellor Allen's Revlon jurisprudence. Finally, Part three concludes with my view of Chancellor Allen's legacy to corporate law. I argue that Chancellor Allen successfully defended the traditional allocation of power over corporate decisionmaking among directors, shareholders, and courts by artfully and insistently rebuffing attempts of the Delaware Supreme Court to expand the role of the courts into areas where they have no useful role. In so doing, Chancellor Allen helped

at 3. Danley's Classical and Managerial positions correspond roughly to descriptions of "contractarian" and "communitarian" views of corporate law. David Millon, Communitarians, Contractarians, and the Crisis in Corporate Law, 50 WASH. \& LEE L. REV. 1373, 1377-78 (1993).

24. For an extended examination of the shareholder primacy norm in the context of ordinary business decisions, see D. Gordon Smith, The Shareholder Primacy Norm, 23 J. CORP. L. (forthcoming 1997).

25. 506 A.2d 173 (Del. 1986).

26. Id. at 182 .

27. Jedwab v. MGM Grand Hotels, Inc., 509 A.2d 584 (Del. Ch. Apr. 11, 1986).

28. Equity-Linked Investors, L.P. v. Adams, CIV. A. No. 15513, 1997 WL 225708, at *1 (Del. Ch. Apr. 25, 1997).

29. As of the date of Chancellor Allen's departure from the bench, the Delaware courts had cited Revlon in 142 decisions. Of those decisions, 19 were by the Delaware Supreme Court, 1 by the Delaware Superior Court, and 122 by the Delaware Court of Chancery. The following was the distribution among judges on the Court of Chancery: Jacobs (35), Allen (33), Hartnett (22), Chandler (18), Berger (12), Steele (1), Duffy (retired Delaware Supreme Court justice sitting by designation) (1). 
to ensure that the appropriate role of the modern corporation in a free society would be decided by individual actors in that society rather than by judicial fiat.

\section{REVLON AND ITS PROGENY IN THE DELAWARE SUPREME COURT}

Revlon was decided by the Delaware Supreme Court in $1985,{ }^{30}$ along with some of the most enduring cases in the history of Delaware corporate law. Perhaps the most significant case decided that year was Unocal Corp. v. Mesa Petroleum Co. (Unocal), ${ }^{31}$ in which the court held that directors have an "enhanced duty" when they take defensive action to thwart a takeover. ${ }^{32}$ It is a misnomer to suggest that the duties of directors are enhanced under Unocal; what is enhanced is the level of scrutiny applied by the reviewing court. The Unocal decision entitled the court to inquire not only into whether the directors "had reasonable grounds for believing that a danger to corporate policy and effectiveness existed because of another person's stock ownership," but also whether any defensive action taken by the board was "reasonable in relation to the threat posed." 33 The first prong of the Unocal standard was old hat, ${ }^{34}$ but the second prong allowed a substantive investigation into director action that was unprecedented absent evidence of some identified conflict of interest. ${ }^{35}$ The rationale for this enhanced scrutiny was not based upon a single conflict to be found under particular circumstances. Rather, the rational centered on the "omnipresent specter that a board may be acting primarily in its own interests, rather than those of the corporation and its shareholders."

Decided after Unocal, Revlon applied enhanced scrutiny to defensive actions taken by the directors of Revlon, Inc. (Revlon) to

30. Although the written decision was not issued until 1986, the Delaware Supreme Court issued an oral decision on Nov. 1, 1985.

31. 493 A.2d 946 (Del. 1985). In addition to Revlon, other major cases decided in 1985 were Moran v. Household International, Inc., 500 A.2d 1346 (Del. 1985) and Smith v. Van Gorkom, 488 A.2d 858 (Del. 1985).

32. Unocal Corp., 493 A.2d at 954.

33. Id. at 949 .

34. The first prong is based on Cheff v. Mathes, 199 A.2d 548 (Del. 1964), which is satisfied "by showing good faith and reasonable investigation." Id. at 555. Although directors bear the burden of proof, this standard is highly deferential to directors in the spirit of the business judgment rule. See Ronald J. Gilson \& Reinier Kraakman, Delaware's Intermediate Standard for Defensive Tactics: Is There Substance to Proportionality Review? 44 BUS. LAW. 247. 249 (1989).

35. Unocal Corp., 493 A.2d at 955.

36. Id. at 954 . 
fend off advances made by Pantry Pride, Inc. (Pantry Pride) ${ }^{37}$ But the reason the Revlon decision is important lies in the court's explanation of the board's duty once a company is "for sale":

The Revlon board's authorization permitting management to negotiate a merger or buyout with a third party was a recognition that the company was for sale. The duty of the board had thus changed from the preservation of Revlon as a corporate entity to the maximization of the company's value at a sale for the stockholders' benefit. This significantly altered the board's responsibilities under the Unocal standards. It no longer faced threats to corporate policy and effectiveness, or to the stockholders' interests, from a grossly inadequate bid. The whole question of defensive measures became moot. The directors' role changed from defenders of the corporate bastion to auctioneers charged with getting the best price for the stockholders at a sale of the company. ${ }^{38}$

Applying this standard to the facts at hand, the court could not seem to decide whether the directors of Revlon, Inc. (Revlon) breached a duty of loyalty or a duty of care. The focus of the court's consternation was that fact that the board of directors of Revlon had favored Forstmann ${ }^{39}$ over Pantry Pride because Forstmann was willing to support the market price of notes previously issued by Revlon to repurchase shares of stock, in an early attempt to ward off Pantry Pride. The court found that this concern for noteholders was inappropriate because their rights "already were fixed by contract." 40 As a result, "when the Revlon board entered into an auction-ending lock-up agreement with Forstmann on the basis of impermissible considerations at the expense of the shareholders, the directors breached their primary duty of loyalty." ${ }^{41}$ A bit later in the opinion, but still in the same section, the court observed, "[ $t$ ]he principal object [of the lock-up agreement with Forstmann], contrary to the board's duty of care, appears to have been protection of the noteholders over the shareholders' interests." 42

The inability of the Delaware Supreme Court to distinguish between the duty of care and the duty of loyalty may seem like so much academic nit-picking, but I believe that it is the source of many

37. Revlon Inc., 506 A.2d at 180.

38. Id. at 182.

39. Forstmann was a named defendant who acted in conjunction with Revlon to block efforts by Pantry Pride to acquire Revlon. Id. at 175.

40. Id. at 182.

41. Id.

42. Id. at 184 . 
of the subsequent problems with the Revlon decision. When claims implicate the duty of care, courts are generally deferential, largely limiting their examination to process issues using the business judgment rule as the standard. On the other hand, when claims implicate the duty of loyalty, courts abandon the business judgment rule and engage in a more searching, substantive review. The Delaware Supreme Court's failure to decide whether Revlon claims implicate the duty of care or the duty of loyalty was a failure to decide the proper role of the courts.

The opinion in Revlon is impenetrable. Beyond the confusion over the duty of care and the duty of loyalty, there is considerable ambiguity over the relationship between Revlon and Unocal. ${ }^{43}$ Although the Court alludes to Unocal in the portion of the opinion discussed above-concluding that "the merger agreement with Forstmann was unreasonable in relation to the threat posed" ${ }^{\prime 4}$-it appeared to create a new standard distinct from Unocal to be applied in the context of a sale of the company. ${ }^{45}$ This ambiguity in turn generated two questions that plague the Delaware court to this day. First, when do the standards embodied in Revlon apply? ${ }^{46}$ Second, what new duties, if any, does Revlon impose?

The Delaware Supreme Court made its first effort to interpret the Revlon duties in Ivanhoe Partners v. Newmont Mining Corp. (Ivanhoe). ${ }^{47}$ However, the court's determination of Revlon's scope in that case has been characterized as "cryptic reasoning." 48 Ivanhoe involved

43. This issue is addressed in some detail below. See infra Part III.

44. Revlon, Inc., 506 A.2d at 182.

45. Although the court refers to the responsibilities of the board as being "under the Unocal standards," it states that the "duty of the board has . . changed." Id. at 182. Elsewhere, the court notes that fending off a hostile bidder-although sometimes appropriate under Unocal一is "no longer a proper objective" once the company is for sale. Id.

46. Ronald Gilson and Reinier Kraakman describe the difficulty with this question:

Revlon ties management's obligations during a takeover event to a discrete event--the point at which the sale of the company becomes inevitable-that is both ambiguous and commonplace, since its occurrence may be difficult to pinpoint in a hostile takeover, and yet it must arise in every friendly acquisition. Within the confines of defending against a hostile takeover, Revlon poses the problem of specifying precisely what action or decision finally trips the board's duty to lay down its arms and discharge "the Revlon obligation to conduct a sale." [Citing Ivanhoe Partners v. Newmont Mining Corp., 535 A.2d 1334, 1338 (Del. 1987).] Outside the setting of a hostile takeover, Revlon raises the open-ended issue of what follows when the identical action or decision occurs in the course of a friendly deal that does not respond to a hostile bid.

Ronald J. Gilson \& Reinier Kraakman, What Triggers Revlon?, 25 WAKE FOREST L. REV. 37, 38 (1990).

47. 535 A.2d 1334 (Del. 1987).

48. See Gilson \& Kraakman, supra note 46 , at 42. 
a defensive recapitalization that transferred effective control over the target corporation to management. ${ }^{49}$ The court concluded that Revlon did not apply because the recapitalization was not a "sale" and did not result in a "bidding contest," even though there was a change of control.

This narrow reading of Revlon did not survive the Delaware Supreme Court's first major pass at Revlon in Mills Acquisition Co. v. Macmillan, Inc. (Macmillan) ${ }^{50}$ Justice Moore, the author of both the Unocal and Revlon opinions, also wrote the court's opinion in the Macmillan case. He summarized the requirements of Revlon duties in general terms:

At a minimum, Revlon requires that there be the most scrupulous adherence to ordinary principles of fairness in the sense that stockholder interests are enhanced, rather than diminished, in the conduct of an auction for the sale of corporate control. ... The sole responsibility of the directors in such a sale is for the shareholder's benefit. The board may not allow any impermissible influence inconsistent with the best interests of the shareholders, to alter the strict fulfillment of these duties. ${ }^{51}$

Later in the opinion, the court provided a more succinct statement of Revlon duties: "[I]n a sale of corporate control the responsibility of the directors is to get the highest value reasonably attainable for the shareholders. Beyond that, there are no special and distinct 'Revlon duties." 52 In Macmillan the court's emphasis on the "best interests of the stockholders" and on the "highest value reasonably attainable" suggests a subtle shift away from the "best price" or sale "to the highest bidder" that was required by Revlon. ${ }^{53}$ Indeed, the court in Macmillan defined the board's Revlon duties as follows: "The proper objective of Macmillan's fiduciaries was to obtain the highest price reasonably available for the company, provided it was offered by a reputable and responsible bidder." ${ }^{4}$ The proviso appears to qualify the board's duties in a manner not contemplated in Revlon. Indeed, the Macmillan court listed many factors that a board might consider in determining whether the bidder is reputable and responsible, including

49. Ivanhoe Partners, 535 A.2d at 1334.

50. 559 A.2d 1261 (Del. 1989).

51. Id. at 1285 .

52. Id. at 1288 (citations omitted).

53. Mills Acquisition Co. v. Macmillan Inc., 559 A.2d at 1285, 1264; Revlon, Inc., 506 A.2d at 182 .

54. Mills Acquisition Co. v. Macmillan Inc., 559 A.2d at 1282 (emphasis added) (citing Revlon, Inc., 506 A.2d at 182, 184). 
not only the adequacy and terms of the offer, but also "the impact of both the bid and the potential acquisition on other constituencies, provided that it bears some reasonable relationship to general shareholder interests," and "the bidders identity, prior background, and other business venture experiences." 55 The court did not explain why any of these things matter.

The court also linked Revlon duties to the enhanced scrutiny standard of Unocal:

As we held in Revlon, when management of a target company determines that the company is for sale, the board's responsibilities under the enhanced Unocal standards are significantly altered. Although the board's responsibilities under Unocal are far different, the enhanced duties of the directors in responding to a potential shift in control, recognized in Unocal, remain unchanged. The principle pervades Revlon, and when directors conclude that an auction is appropriate, the standard by which their ensuing actions will be judged continues to be the enhanced standard imposed by this Court in Unocal. ${ }^{56}$

This general statement of the nexus between Unocal and Revlon, which at first blush seems almost plausible, is incoherent in application. The two-pronged test in Unocal contemplates an outside threat to shareholder interests and a defensive action by the board of directors in response to that threat. In cases implicating Revlon, on the other hand, "[ $t]$ he whole question of defensive measures became moot." 57 The court attempts to gloss over this conceptual problem by claiming that Revlon involves the application of "enhanced scrutiny," even if the two-pronged test, "of necessity, is slightly different." 58 Revlon's version of enhanced scrutiny proceeds as follows:

At the outset, the plaintiff must show and the trial court must find, that the directors of the target company treated one or more of the respective bidders on unequal terms. It is only then that the twopart threshold requirement of Unocal is truly invoked. . . .

In the face of disparate treatment, the trial court must first examine whether the directors properly perceived that shareholder interests were enhanced. In any event, the board's action must be reasonable in relation to the advantage sought to be achieved, or

55. Id. at 1282 n.29.

56. Id. at 1287 (citations omitted).

57. Revlon, Inc., 506 A.2d at 182.

58. Mills Acquisition Co. v. Macmillan Inc., 559 A.2d at 1288. 
conversely, to the threat which a particular bid allegedly poses to stockholder interests. ${ }^{59}$

Because the Macmillan case involved an undisputed "sale" of a company, the court was not required to examine the issue of when Revlon duties are triggered. Nevertheless, in an aside, the court implied that the enhanced scrutiny of Unocal applied to all cases "where issues of corporate control are at stake." ${ }^{60}$ This brief remark could be read to suggest a change in justification for enhanced scrutiny. In Unocal the application of enhanced scrutiny to defensive actions was justified by reference to the "omnipresent specter" of director self interest. ${ }^{61}$ The application of enhanced scrutiny in Macmillan seemed justifiable on a similar conflict-of-interest basis because one bidder was favored over another in a takeover contest, thus raising the possibility of foul play. But the court's broader language raised potential conceptual problems for enhanced scrutiny, as suggested by Professor Paul Regan:

In borrowing Unocal's "omnipresent specter" rationale for use in the Revlon context, the Macmillan court did not explain why the motives of a predominantly disinterested board should automatically be regarded with suspicion. Certainly questions of improper motive do not arise simply because directors have decided to sell the company. . . . Something more-like the "disparate treatment" of competing bidders-would appear to be required before enhanced scrutiny would be triggered in an auction. ${ }^{62}$

59. Id. Such legal reasoning is so often referred to as "tortured," that the designation has become trite. In this case, however, even the fresh application of the word "tortured" would not adequately reflect the court's treatment of Revlon because it implies that some remnant of Revlon could survive such a beating. Surely the Court of Chancery should be forgiven for failing to extract such an interpretation from reading Unocal and Revlon. Indeed, the Delaware Supreme Court seemed very willing to cut the Court of Chancery some slack:

It is not altogether clear that, since our decision in Revlon, the Court of Chancery has explicitly applied the enhanced Unocal standards in reviewing such board actions [citations omitted]. On the surface, it may appear that the trial court has been applying an ordinary business judgment rule analysis. However, on closer scrutiny, it seems that there has been a de facto application of the enhanced business judgment rule under Unocal. To the extent that this has caused confusion, we think it is more a matter of semantics than of substance.

Id. (emphasis added).

60. Id. at 1287.

61. Unocal Corp., 493 A.2d at 954.

62. Paul L. Regan, The Unimportance of Being Earnest: Paramount Rewrites the Rules for Enhanced Scrutiny in Corporate Takeovers, 46 Hastings L. J. 125, 169 (1994). For an endorsement of the change-of-control trigger for Revlon, see Gilson \& Kraakman, supra note 46. 
Although the Delaware Supreme Court subsequently held that the Revlon standards applied to all change-of-control transactions, ${ }^{63}$ the court appeared to hedge on this issue in the well-known case of Paramount Communications, Inc. $v$. Time Inc. (Time). ${ }^{64}$ As discussed below, Chancellor Allen declined to apply Revlon to the actions of Time Inc.'s (Time) directors, reasoning that the merger between Time and Warner Communications, Inc., was not a change of control. The Delaware Supreme Court held that "his conclusion is correct as a matter of law," but elected to base its decision on different grounds. ${ }^{65}$ The court then famously attempted to define the circumstances in which Revlon duties were to be applied:

Under Delaware law there are, generally speaking and without excluding other possibilities, two circumstances which may implicate Revlon duties. The first, and clearer one, is when a corporation initiates an active bidding process seeking to sell itself or to effect a business reorganization involving a clear break-up of the company. However, Revlon duties may also be triggered where, in response to a bidder's offer, a target abandons its long-term strategy and seeks an alternative transaction involving the breakup of the company. ${ }^{66}$

This formulation-leaving open "other possibilities" than those listed for the application of Revlon duties-created substantial ambiguity. On the other hand, the court was abundantly clear in its view that Revlon triggered duties that were distinct from Unocal duties. ${ }^{67}$

The court fully embraced changes in corporate control as the triggering event for Revlon duties in Paramount Communications $v$. QVC Network Inc. (Paramount), stating:

The decisions of this court have clearly established the circumstances where ... enhanced scrutiny will be applied. The case at bar implicates two such circumstances: (1) the approval of a transaction resulting in a sale of control, and (2) the adoption of defensive measures in response to a threat to corporate control. ${ }^{68}$

63. See, e.g., Barken v. Armsted Industries, 567 A.2d 1279, 1286 (Del. 1989) ("We believe that the general principles announced in Revlon [and] in Unocal . . govern this case and every case in which a fundamental change of corporate control occurs or is contemplated.").

64. 571 A.2d 1140 (Del. 1989).

65. Id. at 1150 .

66. Id. (citations omitted).

67. The court reasoned: "If, however, the board's reaction to a hostile tender offer is found to constitute only a defensive response and not an abandonment of the corporation's continued existence, Revlon duties are not triggered, though Unocal duties attach." Id. at 1150-51.

68. 637 A.2d 34, 42 (Del. 1994) (citations omitted). 
The rationale for applying enhanced scrutiny to all change-ofcontrol transactions lay not in the "omnipresent specter" of director self interest, ${ }^{69}$ but rather in the significance of such transactions to shareholders, which the court described as follows:

Because of the intended sale of control, the [acquisition of Paramount by Viacom] has economic consequences of considerable significance to the Paramount stockholders. Once control has shifted, the current Paramount stockholders will have no leverage in the future to demand another control premium. As a result, the Paramount stockholders are entitled to receive, and should receive, a control premium and/or protective devices of significant value. ${ }^{70}$

According to the court, change-of-control transactions are so important that courts should review the reasonableness of director action, even if the directors are disinterested. ${ }^{71}$ It is not clear what the court thought it had to add by such an intrusion, given its view that " $[t]$ here are many business and financial considerations implicated in investigating and selecting the best value reasonably available. The board of directors is the corporate decisionmaking body best equipped to make these judgments."72

Paramount is the Delaware Supreme Court's most recent effort to reformulate Revlon, ${ }^{73}$ but in subsequent cases, the court has narrowed its understanding of "change of control" to accord with Chancellor Allen's opinion in Time. ${ }^{74}$

69. Unocal Corp., 493 A.2d at 954.

70. Paramount Communications v. QVC Network Inc., 637 A.2d at 43. The court went on to say that, although the directors have the same duties of care and loyalty in a sale-of-control context that they possess in other contexts, "[i]n pursuing [the sale], the directors must be especially diligent." Id. at 44 .

71. Id. at 45. Paul Regan called the court's decision "an unwarranted expansion of the role of the courts in the context of corporate takeovers" and argued that "Paramount's transactionsignificance rationale represents a substantial departure from Delaware's traditional model of corporate governance." Regan, supra note 62, at 190-91.

72. Paramount Communications v. QVC Network Inc., 637 A.2d at 45.

73. Id. at 44.

74. For a discussion of Chancellor Allen's opinion in the Time case, see infra notes 112-14 and accompanying text. In Amold v. Soc'y for Sav. Bancorp., Inc., 650 A.2d 1270 (Del. 1994), the Delaware Supreme Court summarized the circumstances in which Revlon applies:

The directors of a corporation "have the obligation of acting reasonably to seek the transaction offering the best value reasonably available to the stockholders," in at least the following three scenarios: (1) "when a corporation initiates an active bidding process seeking to sell itself or to effect a business reorganization involving a clear break-up of the company"; (2) "where, in response to a bidder's offer, a target abandons its longterm strategy and seeks an alternative transaction involving the break-up of the company"; or (3) when approval of a transaction results in a "sale or change of control." In the latter situation, there is no "sale or change in control" when " ' $c]$ ontrol of both 
The court later held that a merger in which the shares would remain "in a large, fluid, changeable and changing market" did not require a Revlon analysis - even though the directors solicited bids-because the directors had not sought to sell control of the company. ${ }^{75}$ Currently, therefore, the court's view of enhanced scrutiny in Revlon cases does not appear to be far removed from its application of the traditional business judgment rule. In both instances, the court will normally defer to the board of directors once it is shown that the directors were well informed and acting in good faith (the first prong of enhanced scrutiny). That deference in the context of the business judgment rule will be overcome only when the actions taken by directors cannot be "attributed to any rational business purpose."76 Under the Paramount holding, the deference is overcome only if "the directors' decision was, on balance, [not] within the range of reasonableness." 77 Whether these two standards are substantively different will be examined in more detail below.

[companies] remain[s] in a large, fluid, changeable and changing market."' Id. at $1289-90$ (citations omitted).

75. In re Santa Fe Pacific Corporation Shareholder Litigation, 669 A.2d 59, 71 (Del. 1995). The Sant $\mathrm{Fe}$ case also contained an important statement about the relationship between enhanced scrutiny and shareholder voting rights:

Permitting the vote of a majority of stockholders on a merger to remove from judicial scrutiny unilateral Board action in a contest for corporate control would frustrate the purposes underlying Revlon and Unocal. Board action which coerces stockholders to accede to a transaction to which they otherwise would not agree is problematic. Thus, enhanced judicial scrutiny of Board action is designed to assure that stockholders vote or decide to tender in an atmosphere free from undue coercion.

Id. at 68 (citations omitted).

76. Sinclair Oil Corp. v. Levien, 280 A.2d 717, 720 (Del. 1971). In Gagliardi v. TriFoods, Inc., 683 A.2d 1049, 1051-52 (Del. Ch. 1996), Chancellor Allen stated:

[I]n the absence of facts showing self-dealing or improper motive, a corporate officer or director is not legally responsible to the corporation for losses that may be suffered as a result of a decision that an officer made or that directors authorized in good faith. There is a theoretical exception to this general statement that holds that some decisions may be so "egregious" that liability for losses they cause may follow even in the absence of proof of conflict of interest or improper motivation. The exception, however, has resulted in no awards of money judgments against corporate officers or directors in this jurisdiction and, to my knowledge only the dubious holding in this Court of Gimbel $v$. Signal Companies, Inc., (Del. Ch.) 316 A.2d 599 affd (Del. Supr.) 316 A.2d 619 (1974), seems to grant equitable relief in the absence of a claimed conflict or improper motivation.

Gagliardi, 683 A.2d at $1051-52$ (footnotes omitted).

77. Paramount Communications v. QVC Network Inc., 637 A.2d at 45. 


\section{Chancellor Allen's Revlon Jurisprudence}

Throughout his tenure on the bench, Chancellor Allen struggled to answer the two questions about the Revlon decision identified above: (1) When are its special duties triggered?, and (2) What do those duties specifically require? ${ }^{78}$ Viewed as a whole, the Delaware judiciary has erected confusing and conflicting standards to divine the answers to those questions. ${ }^{79}$ As a trial court judge, Chancellor Allen was required to work within the constraints imposed by the Delaware Supreme Court, but he managed to build a startlingly simple and consistent approach to Revlon's strictures that has varied surprisingly little over the course of his tenure on the court. His steadiness-a marked contrast to the erratic and meandering jurisprudence of the Delaware Supreme Court-can be traced to the fact that Chancellor Allen viewed Revlon as a duty of loyalty case from the beginning, ${ }^{80}$ whereas the Delaware Supreme Court is still uncertain, having recently

78. Equity-Linked Investors, L.P.v. Adams, CIV. A. No. 15513, 1997 WL 225708, at *12 (Del. Ch. Apr. 25, 1997).

79. For a description of various fiduciary duty doctrines in the Delaware cases, see Lawrence A. Cunningham \& Charles M. Yablon, Delaware Fiduciary Duty Law After QVC and Technicolor: A Unified Standard (and the End of Revlon Duties?), 49 BUS. LAW. 1593, 1609-14 (1994).

80. See, e.g., In re J.P. Stevens \& Co., Inc. Shareholders Litigation, 542 A.2d 770 (Del. Ch. Apr. 8, 1988) ("if Revlon is explained as a duty of loyalty case (i.e., one in which the board appeared not to be acting in good faith for the shareholders' benefit), which is how I read it. ..."); In re Fort Howard Corp. Shareholders Litigation, CIV. A. No. 9991, 1988 WL 83147, at *14 (Del. Ch. Aug. 8, 1988) ("I understand [Revlon] as essentially a breach of loyalty case in which the board was not seen as acting in the good faith pursuit of shareholders' interests.").

The only time Chancellor Allen introduced confusion on this issue was in his personal liability opinion in Cinerama, Inc. v. Technicolor, Inc., CIV. A. No. 8358, 1991 WL 111134 (Del. Ch. Jun. 24, 1991). The plaintiffs in that case did not allege a duty of loyalty violation; they argued instead that the directors were grossly negligent and that they violated their duty under Revlon to maximize shareholder value. Chancellor Allen treated these two allegations as one, stating:

[W] here there is no breach of loyalty pleaded . . . the due care theory and the Revlon theory do not present separate legal theories justifying shareholder recovery. [citation omitted] In such a context, both theories reduce to a claim that directors were inadequately informed (of alternatives, or of the consequences of executing a merger and related agreements). An auction is a way to get information. A pre- or post-agreement market-check mechanism is another, less effective but perhaps less risky, way to get information. ...

Id. at *16.

Of course, courts feel perfectly comfortable evaluating the information gathering process under the business judgment rule, and this aspect of Revlon does not account for its uniqueness. Rather, Revlon was intended to be different because it allowed the court to exercise a more searching review of director action in situations where the "omnipresent specter" of self interest is present. Under this view, Revlon is necessarily a duty of loyalty case. 
written, "Revlon and Unocal and the duties of a Board when faced with a contest for corporate control do not admit of easy categorization as duties of care or loyalty." 81 As a duty of loyalty case, Revlon would require application only when the board of directors has a found conflict. The role of the courts is clear and confined to cases where they might be expected to do some good.

Because of this reading of Revlon, Chancellor Allen's opinions are based on a belief that Revlon does not fundamentally challenge the traditional structure of corporate law, which holds that directors should be allowed to make business decisions without judicial interference as long as they are acting independently, in good faith, with adequate information, and within the bounds of rationality. By comparison, the Delaware Supreme Court seems intent on creating new and innovative doctrines of corporate law without much regard for the animating theories underlying the doctrines. As a result, the Revlon jurisprudence of the Delaware Supreme Court seems sporadic and difficult to apply in future transactions.

The following sections organize Chancellor Allen's Revlon decisions according to the three most important Delaware Supreme Court cases discussed above: Revlon, Macmillan, and Paramount. Chancellor Allen's ability to steer a straight course in such rough waters is the defining characteristic of his substantial abilities as a judge.

\section{A. The Revlon Era}

In the first cases following Revlon, Chancellor Allen cited Revlon for the proposition that directors do not owe fiduciary duties to creditors $^{82}$ or for a statement of the standard used to evaluate preliminary injunctions. ${ }^{83}$ Prior to the Delaware Supreme Court's oral decision in Macmillan, Chancellor Allen decided only three cases in which he wrestled with the core questions about Revlon. ${ }^{84}$ Before the

81. In re Santa Fe Pacific Corporation Shareholder Litigation, 669 A.2d at 67, citing Ivanhoe Partners v. Newmont Mining Corp., 535 A.2d at 1345.

82. See Jedwab v. MGM Grand Hotels, Inc., 509 A.2d 584, 593 n.5 (Del. Ch. Apr. 11 , 1986); Kass v. Eastern Air Lines, Inc., 1986 WL 13008, at 3 (Del. Ch. Nov. 14, 1986) (memorandum opinion).

83. See, e.g., Citron v. Steego Corp., CIV. A. No. 10171, 1988 WL 94738, at *2 (Del. Ch. Sept. 9, 1988); In re Anderson, Clayton Shareholders Litigation, 519 A.2d 680, 686 (Del. Ch. Jun. 6, 1986).

84. See In re Fort Howard Corp. Shareholders Litigation, CIV. A. No. 9991, 1988 WL 83147 (Del. Ch. Aug. 8, 1988); In re J.P. Stevens \& Co., Inc. Shareholders Litigation, 542 A.2d 770 (Del. Ch. Apr. 8, 1988); Freedman v. Restaurant Associates Industries, Inc., 1987 WL 14323 (Del. Ch. Oct. 16, 1987) (memorandum opinion). 
written decision in Macmillan was issued, Chancellor Allen had decided three additional important Revlon cases. ${ }^{85}$ Although these decisions were rendered in the shadow the Delaware Supreme Court's bench ruling in Macmillan, their analysis seems only marginally affected by the ruling, and they are best grouped with the other cases in the Revlon era.

Allen's first attempt to define the reach of Revlon came two years after the Revlon decision. In Freedman v. Restaurant Associates Industries, Inc. (Freedman), he stated: "The Revlon case recognizes an obligation on the part of the board of directors, once it is clear to the board that the corporation is to be subject to a change of control, to attempt to maximize the amount to be received by shareholders." 86 Despite Allen's implication that Revlon applied to any change-ofcontrol transaction, he declined to apply Revlon in this case because an independent special committee of the board "was appropriately constituted, well advised and active," and "the results it achieved bespeak an aggressive and effective attempt to maximize public shareholder value." ${ }^{87}$ Although Chancellor Allen's reference to the results achieved by the special committee might in retrospect be viewed as a "de facto application of the enhanced business judgment rule under Unocal," ${ }^{88}$ the Freedman opinion later clarifies his reliance on the stripped-down version of the business judgment rule. In deferring to a special committee decision to refuse a request for a lock-up option, Chancellor Allen wrote:

This court has no special expertise in making the judgment concerning whether it would be wise or foolish to incur the risks that further pursuit of [the] proposal inevitably entails; to the contrary, one of the important reasons for the existence of the business judgment rule is the institutional incompetence of courts to pass upon the wisdom of business decisions. Plaintiffs have failed utterly to offer any legal justification for the court's second-guessing the decision of the special committee. ${ }^{89}$

The most important of Chancellor Allen's early Revlon decisions is In re J.P. Stevens E Co., Inc. Shareholders Litigation (J.P. Stevens)

85. TW Services, Inc. v. Crown, CIV. A. No. 10427, 10298, 1989 WL 20290 (Del. Ch. Mar 2, 1989); In re RJR Nabisco, Inc. Shareholders Litigation, CIV. A. No. 10389, 1989 WL 7036 (Del. Ch. Jan. 31, 1989); City Capital Associates Ltd. Partnership v. Interco Inc., 551 A.2d 787 (Del. Ch. Nov. 1, 1988).

86. Freedman, $1987 \mathrm{WL} 14323$, at *6.

87. Id. at *7.

88. Mills Acquisition Co. v. Macmillan, Inc., 559 A.2d at 1288 (emphasis added).

89. Freedman, 1987 WL 14323 , at $* 8$. 
which involved a battle between competing tender offerors. ${ }^{90}$ In deciding whether the board of directors of the target corporation had breached its fiduciary duties, Chancellor Allen considered two possible interpretations of Revlon:

First, Revlon can be seen as a case essentially involving a board that, if not disloyal to shareholder interests, was in a conflict situation. This divided loyalty ... justified the court, under conventional doctrine, in reviewing the substantive fairness of the various board actions there taken. Alternatively, Revlon may be viewed as a case in which a finding of divided loyalty did not play a critical part. On this view, the case establishes some rules about the kind of agreements that may not be entered during an auction for corporate control (e.g., those that will stop the bidding or that will favor one bidder over another) even by a disinterested, fully functioning board or, at the least, will call forth active judicial review of the wisdom or fairness of such contracts. ${ }^{91}$

As between these two views, Revlon itself is agnostic. Chancellor Allen notes that Revlon "does not purport to restrict the powers of a disinterested board from entering into agreements" that provide for topping fees and expense reimbursements, as long as "the board acts in good faith and with appropriate care." 92 By the same token, one might argue, Revlon does not require an actual conflict of interest before the reviewing court is allowed to evaluate the reasonableness of the board's actions. All that is required to justify that more searching review is the "omnipresent specter" of self-interest, and surely an agreement that creates an impediment to further bids raises the specter of self-interest. In short, Revlon does not mandate either approach proposed by the parties in the J.P. Stevens case. On what basis then, did Chancellor Allen reject the more expansive view of Revlon in favor of an approach employing the business judgment rule?

Unfortunately, Chancellor Allen does not explain the basis for his decision beyond conclusory comments such as: "[I]f Revlon is viewed as a duty of loyalty case ...., which is how I read it," 93 and, in response to one party's argument for an expansive reading, "I do not

90. 542 A.2d 770 (Del. Ch. Apr. 8, 1988). Chancellor Allen begins the analysis portion of this opinion with this observation about the case: "It seems hardly an exaggeration to say that plaintiffs' argument . . . begins and ends with the Delaware Supreme Court's opinion in Revlon." Id. at 778 .

91. Id. at 779 .

92. Id. at 781-82.

93. Id. at 781 . 
so understand that case."94 Reading between the lines, however, it appears that Chancellor Allen was simply unwilling to interpose his views where those of independent directors acting in good faith and on reasonable investigation have already been heard. ${ }^{95}$ Stated another way, Chancellor Allen seemed to approve of the traditional relationship between courts and the judiciary, where judges interject themselves only when the board of directors appears not to be properly motivated to act in the best interests of the stockholders.

Chancellor Allen revisited Revlon in In re Fort Howard Corp. Shareholders Litigation (Fort Howard), which involved an auction following the announcement of a proposed management buyout. ${ }^{96}$ Chancellor Allen expanded on the views he had expressed in J.P. Stevens, reiterating that he did not see the need for enhanced scrutiny when the board of directors was disinterested, well-informed, and acting in good faith. ${ }^{97}$ Indeed, when a board of directors exhibits those characteristics, it might favor one bidder over another (as happened in Fort Howard) without triggering enhanced scrutiny:

[A] board need not be passive even in an auction setting. It may never appropriately favor one buyer over another for a selfish or inappropriate reason, such as occurred in Revlon, but it may favor one over another if in good faith and advisedly it believes shareholder interests would be thereby advanced.... The need to exercise judgment is inescapably put on the board at points in an auction process and the validity of the exercise of that judgment is appropriately subjected to a business judgment form of judicial review. $^{98}$

Chancellor Allen's repeated application of the business judgment rule to Revlon claims suggests that he viewed Revlon as an extension

94. Id.

95. For example, Chancellor Allen refers critically to a hypothetical judge who is "inclined to second guess board decisions." Id. at 779. He later states, "I do not regard myself as authorized by Unocal or any other precedent of this court or the [Delaware] Supreme Court to pass upon the reasonableness of the [board's] judgment," $i d$. at 780 , and argues that the issues raised in the case are "precisely the sort of debatable questions that are beyond the expertise of courts and which the business judgment rule generally protects from substantive review for wisdom." Id. at 783. Finally, Chancellor Allen contends that even if an agreement skews the "level playing field" of the auction, the court has no call to set aside the agreement, as long as it was concluded by a board that was independent and acting in good faith on an informed basis. Id. at 783-84.

96. In re Fort Howard Corp. Shareholders Litigation, CIV. A. No. 9991, 1988 WL 83147, at $* 1$ (Del. Ch. Aug. 8, 1988).

97. In re J.P. Stevens \& Co., Inc. Shareholders Litigation, 542 A.2d 770, 779 (Del. Ch. Apr. 8, 1988).

98. In re Fort Howard Corp. Shareholders Litigation, 1988 WL 83147, at *14. 
of traditional doctrines of corporate law rather than as a revolutionary new regime. Indeed, he stated as much in City Capital Associates Ltd. Partnership $v$. Interco Inc., where he strove to place Revlon in the context of traditional fiduciary duty law. ${ }^{99}$ He summarized the teachings of J.P. Stevens, Fort Howard and Vice-Chancellor Jacobs' decision in Macmillan as follows:

The contours of a board's duties in the face of a takeover attempt are not, stated generally, different from the duties the board always bears: to act in an informed manner and in the good faith pursuit of corporate interests and only for that purpose. Unocal, of course, adds that where the board acts to defeat such an offer, its steps must be reasonable in light of the threat created by the offer. But I do not think that Revlon intended to narrowly circumscribe the range of reactions that a board may make in good faith to an attempt to seize control of a corporation. Even when the corporation is clearly "for sale," a disinterested board or committee maintains the right and the obligation to exercise business judgment in pursuing the stockholders' interest. ${ }^{100}$

Chancellor Allen did not stop at that, but took pains to explain that Revlon "can be seen as an application of traditional Delaware law" and "should not . . . be interpreted as representing a sharp turn in our law."101 As in previous cases, the lodestar for director action is "the best interest of the shareholders," 102 and an auction is simply a method of gathering information about the value of the company. Chancellor Allen argued, however, that directors might fulfill their duty to be informed without conducting an auction. ${ }^{103}$

In spite of his efforts to blend Revlon into traditional corporate norms, Chancellor Allen recognized distinct "Revlon duties." The exact contours of those duties, however, remained unclear. The J.P. Stevens and Fort Howard holdings both showed that Revlon duties did not require a board to maintain a level playing field in an auction, but to pursue the best interests of stockholders. ${ }^{104}$ In Citron v. Fairchild

99. 551 A.2d 787, 801 (Del. Ch. Nov. 1, 1988).

100. Id. at 802 . In re RJR Nabisco, Inc. Shareholders Litigation involved an auction in which two bidders offered "substantially equivalent" bids. Chancellor Allen again rejected the notion that Revlon imposed fiduciary duties independent of the duty of care and duty of loyalty. 1989 WL 7036, at 20 (Del. Ch. Jan. 31, 1989).

101. City Capital Assaciates Ltd. Partnership, 551 A.2d at 802.

102. Id.

103. Id. at $802-03$.

104. In re J.P. Stevens \& Co., Inc. Shareholders Litigation, $542 \mathrm{~A} .2 \mathrm{~d}$ at 780 ; In re Fort Howard Corp. Shareholders Litigation, 1988 WL 83147, at *14. 
Camera and Instrument Corp. ${ }^{105}$ Chancellor Allen stated: "[P]laintiff is certainly incorrect to assert that [Revlon] recognized a duty on the part of directors when a corporation is 'for sale,' to get the highest available price. Rather, the duty can only be to try in good faith, in such a setting, to get the best available transaction for the shareholders. Directors are not insurers." ${ }^{06}$ The phrase "best available transaction" implies that factors other than price might be considered. ${ }^{107}$

Chancellor Allen backed away from this view in TW Services $v$. SWT Acquisition Corp. (TW Services), when he observed that Revlon makes the duty of directors "more targeted and specific" than usual, requiring a board in a sales transaction to "exercise judgment (in good faith and prudently) in an effort to maximize immediate share value."108 Chancellor Allen's focus on price is a shift from the more nebulous requirement that the board obtain the "best available transaction" for shareholders. Although justifiable from a reading of Revlon and other cases, ${ }^{109}$ the language is jarring in a Chancellor Allen opinion because he had previously taken pains to emphasize that price was not the only metric by which to measure board action.

$T W$ Services gave Chancellor Allen his first opportunity to evaluate the distinction between managing a company for the long term and managing a company to maximize current stock prices. He asked:

May a board find itself thrust involuntarily into a Revlon mode in which it is required to take only steps designed to maximize current share value and in which it must desist from steps that would impede that goal, even if that might otherwise appear sustainable as an arguable step in the promotion of "long term" corporate or share values? 110

Chancellor Allen answered that question by concluding that a board is allowed to decline overtures for an acquisition, even if the offered price exceeds the current value of the corporation's stock. The board's decision is evaluated under the business judgment rule.

In the years following Revlon and preceding Macmillan, Chancellor Allen saw a limited role for judicial intervention in change-ofcontrol transactions. He did not apply the enhanced scrutiny of Revlon

105. CIV. A No. 6085, 1988 WL 53322 (Del. Ch. May 19, 1988).

106. Id. at * 21 n.17.

107. In re J.P. Stevens \& Co., Inc. Shareholders Litigation, 542 A.2d at 781 n.6.

108. Civ. A. Nos. 10427, 10298, 1989 WL 20290, at *7 (Del. Ch. Mar. 2, 1989).

109. See, e.g., Ivanhoe Partners v. Newmont Mining, 535 A.2d 1334, 1344-45 (Del. 1987) (citing Chancellor Allen's discussion of the Board's need to secure the highest price in conjunction with its duties of loyalty and care).

110. TW Services, 1989 WL 20290 , at $* 8$. 
in the Freedman case. He did not apply it in J.P. Stevens. And, he did not apply it in Fort Howard, Interco, RJR Nabisco, or TW Services. In all of these cases, Chancellor Allen found evidence of self-interested behavior on the part of the board of directors insufficient to trigger judicial review of the reasonableness of board actions. ${ }^{111}$ According to Chancellor Allen, Revlon mandated reasonableness review only when the board acted out of self interest, in bad faith, or without sufficient information. In extremely limited circumstances, a court might engage in substantive review if a board action "is so far beyond the bounds of reasonable judgment that is seems essentially inexplicable on any ground other than bad faith."112

\section{B. The Macmillan Era}

Shortly after the Delaware Supreme Court published its opinion in Macmillan, Chancellor Allen addressed one of the most visible merger cases in history, Paramount Communications Inc. v. Time Inc. ${ }^{113}$ Surprisingly, Chancellor Allen's view of Revlon appears to have altered little, if at all, as a result of the Macmillan case as shown by his decision in Time. As with all of his previous decisions in which Revlon formed a prominent part, he declined to find that Revlon duties had been triggered..$^{114}$ In this instance, he held that a stock-for-stock exchange of two publicly traded companies did not result in a change in control because "[c]ontrol of both remained in a large, fluid, changeable and changing market." $115 \mathrm{He}$ also declined the plaintiffs' invitation to extend Revlon beyond sales or other changes in control to cover the situation where a present transaction might preclude a future change in control (thus denying shareholders the ability to obtain a control premium). ${ }^{116}$ In the process, he again noted his conviction

111. It is unclear what Chancellor Allen would have done if he had been presented with such evidence. Presumably, evidence of self-interested behavior would result in a review of the substantive fairness of the transaction, but Unocal and Revlon are intended to function as intermediate standards (between the business judgment rule and fairness review), requiring only "reasonableness." And this level of review is not triggered by found conflicts of interest, but rather by the "omnipresent specter" of such conflicts.

112. In re J.P. Stevens \& Co., Inc. Shareholders Litigation, $542 \mathrm{~A} .2 \mathrm{~d}$ at 780 . This is simply Chancellor Allen's restatement of the oft-quoted "rational business purpose" test from Sinclair Oil Corp. v. Levien, 280 A.2d 717, 720 (Del. 1971).

113. 1989 WL 79880 (Del. Ch. Jul. 14, 1989).

114. Id. at $* 23-* 24$.

115. Id. at *23.

116. Id. at *23-*25. 
that "Revlon was not a radical departure from existing Delaware, or other, law." 117

Chancellor Allen's most informative discussion of the Revlon decision during the Macmillan era is found in Roberts v. General Instrument Corp. (Roberts). ${ }^{118}$ In that case, Chancellor Allen expressed his frustration with the Delaware Supreme Court's attempt in the Macmillan case to clarify the relationship between Unocal and Revlon:

In each instance where the board is not predominantly self-interested or under the control or dominating influence of a person with a conflicting interest, the principal judicial inquiries relate to whether the board was adequately informed and acting in good faith. This court has been pointedly instructed, however, that "where issues of corporate control are at stake" action of even a disinterested board must meet an enhanced test before they will qualify for the deference that courts ordinarily accord to good faith business judgments. ${ }^{119}$

Allen then restated the enhanced scrutiny standard for Revlon cases as follows:

In such a setting the additional level of inquiry comes to this: whether the circumstances afford a disinterested and well motivated director a basis reasonably to conclude that if the transactions contemplated by the merger agreement close, they will represent the best available alternative for the corporation and its shareholders. ${ }^{120}$

Roberts thus raises starkly the crucial question for purposes of Revlon's viability as a separate fiduciary standard: Is substantive review under Revlon materially different than substantive review under the business judgment rule? ${ }^{121}$ The answer to this question is elusive

117. Id. at *25.

118. CIV. A No. 11639, 1990 WL 118356 (Del. Ch. Aug. 13, 1990).

119. Id. at *8.

120. Id. See also Freedman v. Restaurant Associates Indus., Inc., CIV. A. No. 9212, 1990 WL 135923, at *6 (Del. Ch. Sept. 21, 1990) ("The obligation of the directors where a transaction is a non-conflict one, is to exercise due care in the good faith pursuit of legitimate goals. When that transaction is the sale of the enterprise an additional level of inquiry-reasonableness-is required."). Unocal:

121. Alan Garfield raised a similar question with respect to the proportionality review of

After Unocal, the question for courts was whether this latter "proportionality" test would be one of substance or of form. Would a defensive action pass the test, for instance, if management simply alleged that there was a "threat" to the corporation, or would courts actually determine whether the threat was credible? Would any defensive 
because the only case in which any Delaware court ultimately imposes its own views under the Revlon reasonableness standard is Paramount. ${ }^{122}$

During the Macmillan era, Chancellor Allen remained true to his belief that Revlon imposed distinctive duties on directors. In Braunschweiger v. American Home Shield Corp., for example, Chancellor Allen wrote:

While the Revlon case does not require that whenever a corporation is to be sold for cash an auction be held, it does require, in my opinion, at the least that directors take reasonable steps designed to assure that they have probed for alternatives and have a reasonable basis to conclude that the choice that they make is the best available alternative. ${ }^{123}$

\section{The Paramount Era}

Chancellor Allen discusses Revlon at some length in only three cases after Paramount. ${ }^{124}$ In each, he begins with the difficult inquiry into whether Revlon applies. As noted above, Paramount requires the application of Revlon to all cases involving a change in control. Perhaps the most interesting fact about Allen's treatment of these three cases is his narrow view of the change-in-control requirement. In two of the cases, Allen concluded that Revlon was inapplicable. ${ }^{125}$ In the third, he assumed (without deciding) that Revlon applied so that he could dispose of the case on the simpler issue of whether the directors breached their Revlon duties. They did not. ${ }^{126}$

action be "reasonable" in relation to a threat, or would courts actually test for proportionality?

Alan E. Garfield, Paramount: The Mixed Merits of Mush, 17 DEL. J. CORP. L. 33, 37 (1991).

122. Paramount Communications Inc. v. Time Inc., 637 A.2d 34, 49.

123. CIV. A No. 107551989 WL 128571, at 6 (Del. Ch. Oct. 26, 1989).

124. Equity-Linked Investors, L.P. v. Adams, CIV. A. No. 15513, 1997 WL 225708 (Del. Ch. Apr. 25, 1997); Wells Fargo \& Co. v. First Interstate Bancorp., CIV. A. Nos. 14696, 4623, 1996 WL 32169 (Del. Ch. Jan. 18, 1996); Mendel v. Carroll, 651 A.2d 297 (Del. Ch. Jun. 17, 1994).

125. In Wells Fargo \& Co. v. First Interstate Bancorp, Chancellor Allen held that Revlon did not apply because the stock-for-stock exchange contemplated in Wells Fargo would not result in the removal of control from the public securities markets. 1996 WL 32169, at *4. In the Mendel case cited above, Chancellor Allen concluded that Revlon was inapplicable when a board of directors refused an acquisition offer at a price higher than the price previously offered by a controlling stockholder group and accepted by the board. Because the controlling stockholders were not buying control, Allen reasoned, Revlon did not apply. Mendel v. Carroll, $651 \mathrm{~A} .2 \mathrm{~d}$ at 304-07.

126. Equity-Linked Investors, L.P., 1997 WL 225708, at *14. 
Once it is concluded that Revlon applies, three important differences between the "Revlon state" and other states of board action come into play. First, in the Revlon state, the board of directors must focus on maximizing the current value of shares held by common stockholders. Normally, a board of directors is allowed to sacrifice current value in pursuit of future value, and its actions are subject to deference under the business judgment rule. In the words of Chancellor Allen, "That is the gist of the Revlon state: to act reasonably to maximize current, not some future, value. (In other states, it is entirely up to the board to exercise judgment over what time-frame the corporation's resources are to be developed and how. . . .)"127

Second, the other duty imposed by Revlon is the duty to "fully consider alternative transactions offered by any responsible buyer." 128 In other contexts, a board is empowered to "just say no" to proffered transactions. In Macmillan, the Delaware Supreme Court wrote:

A refusal to entertain offers may comport with a valid exercise of business judgment. Circumstances may dictate that an offer be rebuffed, given the nature and timing of the offer; its legality, feasibility and effect on the corporation and the stockholders; the alternatives available and their effect on the various constituencies, particularly the stockholders; the company's long-term strategic plans; and any special factors bearing on stockholder and public interests. ${ }^{129}$

Third, the standard of review of Revlon claims is more searching than for claims calling for application of the business judgment rule. Chancellor Allen's final Revlon decision-Equity-Linked Investors, L.P. v. Adams (Adams) - provides important insights on his understanding of the obligations imposed on courts by Revlon. He begins his analysis of Adams with a short history of the judicial treatment of Revlon by the Delaware courts, identifying two general views of Revlon: (1) the "regulatory" view exemplified by Macmillan cast the court in an

127. Id. at *14. See also Wells Fargo \& Co., 1996 WL 32169, at*4 n.3.

128. Wells Fargo $\mathcal{E}$ Co., 1996 WL 32169 , at *4 n.3. See also Equity-Linked Investors, L.P., 1997 WL 225708, at*13.

129. Mills Acquisition Co. v. Macmillan, Inc., 559 A.2d 1261, 1285 n.35. See also Paramount Communications v. Time Inc., 571 A.2d 1140, 1151 - 52 (Del. 1989); Pogostin v. Rice, 480 A.2d 619, 627 (Del. 1984). The "just say no" defense to unwanted takeover offers has been approved in subsequent Delaware cases. See, e.g., Moore Corp. v. Wallace Computer Servs., 907 F. Supp. 1545 (D. Del. 1995) (refusal of a board to redeem a poison pill in the face of an abovemarket, all-cash offer for all shares was allowed); Paramount Communications v. QVC Network, Inc., $637 \mathrm{~A} .2 \mathrm{~d}$ at $34,43 \mathrm{n} .13$ ("where a potential sale of control by a corporation is not the consequence of a board's action, this Court has recognized the prerogative of a board of directors to resist a third party's unsolicited acquisition proposal or offer"). 
aggressive posture, reviewing board actions for fairness whenever the corporation was "for sale" and "limit[ing] the range of good faith business judgment that the board might make"; ${ }^{130}$ and (2) the "normalizing" view exemplified by Chancellor Allen's early opinions cast the court in a deferential ("business-judgment like") posture with respect to decisions of an independent board of directors, even in the context of a "sale."131 According to Chancellor Allen, the Delaware Supreme Court's opinion in Paramount Communications v. QVC Network" ${ }^{132}$ requires an "intermediate level of judicial review which recognizes the broad power of the board to make decisions in the process of negotiating and recommending a 'sale of control' transaction, so long as the board is informed, motivated by [a] good faith desire to achieve the best available transaction, and proceeds 'reasonably."'133

Other than the last aspect of the test-relating to the reasonableness of the board's actions-this formulation of the standard of review is exactly the same as the business judgment review that Chancellor Allen applied in the early Revlon cases. The reasonableness review is the "enhanced" aspect of this standard, but even this may not differ much in practice from Chancellor Allen's business judgment review. In J.P. Stevens, he stated that the reviewing court must determine whether the board's action "is so far beyond the bounds of reasonable judgment that it seems essentially inexplicable on any ground other than bad faith." 134

Comparing the J.P. Stevens case with the Adams case is instructive. In both cases, Chancellor Allen found that the directors were well informed and had acted in good faith, and that the ultimate resolution of the case rested on whether the directors had acted reasonably. In J.P. Stevens, the substantive inquiry into reasonableness was part of the business judgment review. ${ }^{135}$ Chancellor Allen's inquiry was designed to determine whether the board's actions were "so beyond the bounds of reasonable judgment in the circumstances as to give rise to an inference of bad faith."136 In pursuing this inquiry, Chancellor Allen confronted a claim that the directors of the target

130. Equity-Linked Investors, L.P., 1997 WL 225708, at *12-"13.

131. Id. at *13. Chancellor Allen summarized the effect of this position as follows: "In this view 'Revlon duties' changed things only by shifting burden of proof and persuasion and by focusing attention on present shareholder value, but it did not fundamentally interfere with the freedom of directors to make good faith business judgment." Id.

132. 637 A.2d 34 (Del. 1994).

133. Equity-Linked Investors, L.P., 1997 WL 225708, at *13.

134. In re J.P. Stevens \& Co., Inc. Shareholders Litigation, 542 A.2d at 780.

135. Id.

136. Id. at 781. 
corporation had breached their fiduciary duties by favoring one tender offeror over another by granting a topping fee. ${ }^{137}$ Whether the topping fee was essential to obtaining a higher bid was a matter over which "reasonable directors, exercising honest, informed judgment, might differ. . . . Certainly, the decision to accede to the topping fee in these circumstances does not fall afield of the expected range of responses to warrant an inference that the Special Committee must have been motivated by concern other than maximizing the value of shareholders' interests." 138 In other words, the actions of the board were reasonable.

In Adams, Chancellor Allen also analyzed the reasonableness of the board's action, asking, "has the board failed reasonably to maximize the current value of the firm's equity?"139 Unlike J.P. Stevens, here the substantive inquiry into reasonableness was not part of the business judgment review, but rather part of the intermediate level of judicial review prescribed by Paramount. In answer to his question, Chancellor Allen again found himself faced with a situation in which reasonable directors might differ:

[U]nlike two competing cash transactions or transactions in which widely traded securities are offered, the alternatives that plaintiff poses are rich with legitimate, indeed unavoidable, occasions for the exercise of good faith business judgment. Where judgment is inescapably required, all that the law may sensibly ask of corporate directors is that they exercise independent, good faith and attentive judgment, both with respect to the quantum of information necessary or appropriate in the circumstances and with respect to the substantive decision to be made. ${ }^{140}$

These cases starkly illustrate the parallel between the substantive inquiry into reasonableness under the business judgment rule and under the intermediate level of review. They are, in fact, identical. Somehow, Chancellor Allen had managed to navigate a course that brought Revlon back to its proper place.

\section{Chancellor Allen's Reputation}

This Article began by inquiring after the source of Chancellor Allen's formidable judicial reputation. The foregoing examination of his Revlon jurisprudence, especially when compared to cases decided

139. Equity-Linked Investors, L.P., 1997 WL 225708, at *14.

140. Id. at *17 (emphasis added). 
by the Delaware Supreme Court, sheds some light on the answer: Chancellor Allen was a great judge partially because he recognized that his role in addressing the fundamental question- "What is the appropriate role of the modern corporation in a free society?"-was a limited one.

Judges are rarely praised for their restraint. ${ }^{141}$ With respect to the fundamental question, however, corporate law has struck a compromise with American society, ${ }^{142}$ requiring corporations to be operated in the best interests of the shareholders, but in the ordinary run of business, not enforcing that duty so strongly that a corporation's board of directors cannot consider the interests of other constituencies. ${ }^{143}$ The Delaware Supreme Court attempted to upset that compromise in takeover cases, but ultimately, the proper role of a corporation in society should not be determined by the Delaware courts. ${ }^{144}$

Marcel Kahan analyzed the takeover cases of the Delaware Supreme Court and came to a surprisingly (given the foregoing analysis) similar conclusion about its Revlon jurisprudence:

[T] he kinds of transactions that trigger heightened scrutiny under Revlon and Unocal follow from the court's view of the proper allocation of power between directors, shareholders, and courts in deciding whether or not to accept a takeover bid. As Delaware courts have repeatedly stated, it is the board of directors that

141. Sachs, supra note 6 , at 783 (observing that activist judges are more renowned than judges who exercise restraint).

142. Chancellor Allen addressed this point in a lecture on the fundamental question:

The questions "What is a corporation?" and "For whose benefit do directors hold power?" are legal questions only in the sense that legal institutions will be required at certain points to formulate or assume answers to them. But they are not simply technical questions of law capable of resolution through analytical rule manipulation. Even less are they technical questions of finance or economics. Rather in defining what we suppose a public corporation to be, we implicitly express our view of the nature and purpose of our social life. Since we do disagree on that, our law of corporate entities is bound itself to be contentious and controversial. It will be worked out, not deduced. In this process, efficiency concerns, ideology, and interest group politics will commingle with history (including our semiautonomous corporation law) to produce an answer that will hold for here and now, only to be tom by some future stress and to be reformulated once more. And so on, and so on, evermore.

William T. Allen, Our Schizophrenic Conception of the Business Corporation, 14 CARDOZOL. REV. 261, 280-81 (1992).

143. See D. Gordon Smith, The Shareholder Primacy Norm, 23 J. CORP. L. (forthcoming 1997).

144. This is the main point argued by William Cary in his oft-cited attack on the Delaware courts. See William L. Cary, Federalism and Corporate Law: Reflections Upon Delaware, 83 YALE L.J. 663 (1974). 
manages the company-a power which includes, with some qualifications, the power to decide whether or not to accept a takeover bid. Shareholders legitimately express their views of how a company should be run by electing directors whose views they share. If shareholders are dissatisfied with a board's decision to reject a takeover bid, their proper response is to elect a different board. Courts should be reluctant to interfere in this interplay of powers, but may have to do so when it fails to function properly. ${ }^{145}$

Although I believe, as a normative matter, that the regime described by Kahan is desirable, ${ }^{146} \mathrm{I}$ do not believe that the Delaware Supreme Court has erected such a structure. In his creative synthesis of Delaware takeover decisions, Kahan attempted to undo much of the criticism levied against the Delaware Supreme Court for its development of the Unocal and Revlon standards by arguing that the court's decisions were consistent and rational. ${ }^{147}$ Unfortunately, Kahan's favorable evaluation of the Delaware Supreme Court rests on a questionable characterization of the relationship between Unocal and Revlon. He suggests that the Unocal standard is highly deferential and focuses on process, ${ }^{148}$ whereas Revlon is demanding and substantive. ${ }^{149}$ The effect is to place power in the hands of independent directors in Unocal cases and in the hands of judges in Revlon cases. The policy underlying this supposed allocation of power is as follows:

Under Unocal, the court does not engage in a substantive review of the decision by independent directors to reject a tender offer because this decision is ultimately reversible by the shareholders themselves. If, however, shareholders are deprived of the ability to override the judgment of the independent directors, a principal rationale for the deferential review standard has evaporated. In such instances, the

145. Marcel Kahan, Paramount or Paradox: An Update, 985 PLI/Corp. 37, 39 (1997). This is a summary of Kahan's position, which he developed at length in Marcel Kahan, Paramount or Paradox: The Delaware Supreme Court's Takeover Jurisprudence, 19 J. CORP. L. 583 (1994).

146. See D. Gordon Smith, Corporate Govemance and Managerial Incompetence: Lessons from Kmart, 74 N.C. L. REV. 1037 (1996).

147. Kahan, Paramount or Paradox, supra note 145, at 585.

148. "Unocal subjects a decision to reject an offer to an enhanced review of the process by which this decision is arrived at, but not to an independent review of the substantive merits of the decision." Kahan, Paramount or Paradox, supra note 145, at 588.

149. "Once in Revlon-mode, procedural factors, such as the approval of independent board members and adequate information, are no longer sufficient for the court to validate the decisions by a target's board. Instead, the court forces the target to give shareholders the opportunity to accept the hostile tender offer and mandates a high degree of impartiality between the boardfavored and the hostile transaction." Id. 
court's only choices are to give the directors the power to reject a tender offer irreversibly, to engage itself in a substantive review of the board decision, or to give shareholders immediate say in whether to accept the tender offer (e.g., by forcing the board to redeem a poison pill). [I]n such instances the court subjects the decisions of the board to the more stringent Revlon review or, if a target board takes certain affirmative defenses, the court will exercise substantive review under the "reasonable relationship" prong of Unocal. ${ }^{150}$

One problem with Kahan's analysis is that his characterization of Unocal as a process standard relies on subsequent interpretations of Unocal, whereas his view of Revlon arises only from a reading of the case. In fact, as noted above, Revlon was decided shortly after Unocal, and both opinions were authored by the same justice, Justice Moore. Moreover, subsequent cases have shown that Revlon's version of enhanced scrutiny has enjoyed as little exertion as Unocal's. Whether one views these two cases as embodying process standards or substantive standards, it seems that they should be treated as having the same roots.

Kahan also wrongly suggests that the Delaware Supreme Court relied on the shareholder vote as a corrective for bad board actions in Unocal. The fact that the court in subsequent decisions has not actively overturned board actions under the proportionality prong of Unocal is not persuasive evidence regarding the "original intent" of Unocal. The language of that decision evinces a commitment to a substantial role for the judiciary in the cases to which it applies. The opinion analogizes Unocal cases to duty of loyalty cases, where the court employs the unquestionably substantive "entire fairness" review. The lack of conflict found in Unocal cases was thought to preclude entire fairness review, but the "omnipresent specter" of self-interest

150. Id. at 592. In addition to the problems discussed below, there is some internal conflict in Kahan's position. He relies on the power of shareholders to "reverse" a board decision in a Unocal situation, but argues that shareholders cannot be expected to reverse in a Revlon situation. He concedes that shareholders could vote against the merger agreement just as they can vote to elect new directors, but he reasons, "This argument would be persuasive if the merger agreement had not been protected by a 'draconian' termination fee and stock option which would have been triggered had Paramount's shareholders not voted in favor of a merger. These measures severely constrained the ability of Paramount's shareholders to 'reverse' the merger agreement, just as the lock-up option Revlon granted to Forstmann severely constrained shareholders' ability to reverse Revlon's decision to reject Pantry Pride's offer." Id. at 596-97. If the only problem with shareholder self-help were the draconian measures found in many merger agreements, why did the court not address such measures directly rather than asking whether the shareholders received the best price? One suspects that the main concern animating the Delaware Supreme Court was the recognition that shareholders rarely vote against the recommendations of their directors, especially when support of the directors will result in a hefty premium. 
justified more searching review than was found under the business judgment rule.

Revlon was explicitly based on Unocal and attempted to apply its enhanced scrutiny to the sale of a company. At first blush, this enhanced scrutiny has some appeal. After all, in the sale of a corporation, courts might be able to easily compare the price agreed to by the board of directors with another price offered and decide in a rather formulaic manner whether the corporation received the best price. Unfortunately, application of such a formula to real transactions proved impossible. Valuation is not an exact science, and comparisons between offers require substantial business expertise, not merely the juxtaposition of two share prices. Therefore, even if the court suspected that directors were acting in a self-interested manner in Revlon cases, there would be the problem of requiring the court to impose its own "business judgment" (an oxymoron in the case of most judges).

In the end, Kahan's defense of the Delaware Supreme Court fails. Revlon and its progeny in the Delaware Supreme Court are rash attempts to assert the importance of the court at the expense of principle, not rational attempts to develop common law rules based on proven principles. Their opinions created a great deal of uncertainty in boardrooms across the nation and were unworthy of the final arbiter of corporate law in the United States. In fairness, the Delaware Supreme Court has rebounded somewhat from the impulsiveness of the 1980s. Arnold v. Society for Save Bancorp, Inc. ${ }^{151}$ and In re Santa Fe Shareholder Litigation ${ }^{152}$ follow Chancellor Allen's lead in narrowing the trigger for Revlon. The court could make further progress by following Chancellor Allen's decision in Adams, interpreting the substantive review under Paramount to be equivalent to the substantive review under the business judgment rule. Better yet, the Delaware Supreme Court could simply dispose of Revlon, as Chancellor Allen almost certainly would have done had he been given the chance.

Despite my praise for Chancellor Allen's Revlon jurisprudence, it has received some brickbats. Lyman Johnson and David Millon call Chancellor Allen's opinion in Time "somewhat discursive"153 and contend that his view of the shareholder primacy norm is incoherent:

151. 650 A.2d 1270, 1289 (Del. 1994).

152. 669 A.2d 59, 67 (Del. 1995).

153. Lyman Johnson \& David Millon, The Case Beyond Time, 45 Bus. LAW. 2105, 2105 (1990). 
Chancellor Allen in effect says that, in one set of cases (Revlon, [City Capital Assoc. Ltd. Partnership v.]Interco, and [Grand Metropolitan Public Ltd. Co. v.] Pillsbury) he prefers the norm of shareholder primacy-whether in its substantive wealth maximization dimension or its procedural choice dimension-over competing values like labor security and minimal indebtedness, while in others (such as Time) he does not. Nowhere, however, has either he or the Supreme Court stated why, or identified a more elemental and authoritative principle that differentiates those two categories. Underlying normative preference remains, unarticulated and unjustified. ${ }^{154}$

This criticism is misplaced. Not only do Johnson and Millon attribute to Chancellor Allen approval of Revlon and Pillsbury-cases that he did not decide but was forced to live with ${ }^{155}$-but their focus on the shareholder primacy norm confuses a commitment to shareholder primacy with a commitment to judicial intervention. Chancellor Allen was an unabashed proponent of shareholder primacy, but he also believed that courts should defer to the shareholders' chosen representatives, the directors, absent some reason to suspect unfairness. Ultimately, Johnson and Millon's criticism of Chancellor Allen fails because they use a constricted view of shareholder primacy, focusing exclusively on the shareholder primacy norm (an aspect of a director's fiduciary duty) rather than on the structural protections under corporate law (such as shareholder voting) that ensure shareholder primacy.

Chancellor Allen's work will easily outlast his critics. Operating under the direction of a higher court with a penchant for creating "new" fiduciary duties, Chancellor Allen consistently expressed his belief in the proven structure of corporate law. In J.P. Stevens, one of his earliest Revlon decisions, he characterized Revlon as fitting comfortably within "conventional doctrine." 156 Despite several important Delaware Supreme Court decisions in subsequent years, Chancellor Allen similarly downplayed the importance of Revlon in Wells Fargo, one of his last opinions on the subject:

154. Id. at $2117-18$.

155. Revlon, of course, was decided by the Supreme Court and was thus binding on Chancellor Allen. The Pillsbury case was decided by retired Delaware Supreme Court Justice Duffy, sitting by designation on the Court of Chancery. The judges of the Court of Chancery strive to remain consistent within the Court. Chancellor Allen, therefore, was bound to reconcile Pillsbury with his own cases. See Grand Metropolitan Public Ltd. Co. v. Pillsbury Co., 558 A.2d 1049 (Del. Ch. Dec. 16, 1988).

156. In re J.P. Stevens \& Co., Inc. Shareholders Litigation, $542 \mathrm{~A} .2 \mathrm{~d}$ at 779. 
Historically, one would say that courts would be slow to impose [a limitation on the board's ability to pursue future value at the expense of current value] except in limited circumstances. . . . And indeed despite the fact that commentators tended to treat the Revlon case as revolutionary, recent cases have made clear that it did not deviate from this tradition very greatly. ${ }^{157}$

Chancellor Allen's consistency is remarkable given the extreme changes in Delaware Supreme Court opinions described above. It is all the more remarkable because the essence of his position was forbearance. Not only did he have tremendous power by virtue of his position, but he had been given license to use that power expansively by a higher court. Many judges would yield to that temptation, ${ }^{158}$ but Chancellor Allen did not.

\section{CONCLUSION}

Several years ago, Chancellor Allen gave a speech at Cardozo School of Law in which he addressed the fundamental question. ${ }^{159}$ Although he claimed not to be a scholar and felt "rather more like a frog that consents to jump onto the biologist's table," 160 his introspection seemed to indicate that he was simultaneously acting as both frog and biologist. In sharing his thoughts, he revealed much about his view of judging and implied that he might agree with the thesis of this Article. He began with a statement that he claimed "will seem trite to scholars, [and] is offered principally to the students":

Corporation law and, indeed, the law generally, is not simply what it may seem at first, a comprehensive system of legal rules. While it is that, it is also a great deal more. People who think of law as a system of legal rules alone fail to understand that law is a social product, inevitably complex, at points inescapably ambiguous, and always dynamic-always becoming something new. ... In order to grasp the dynamic feature of legal rules, it is necessary to see them

157. 1996 WL 32169, at *4 n.3. Although no citations were provided, the "recent cases" to which Chancellor Allen refers surely include Paramount, which he later said had "narrowed the range of corporate transactions to which the principle of Revlon applies." Equity-Linked Investors, L.P., 1997 WL 225708, at *13.

158. Joseph Smith, the founder of the Church of Jesus Christ of Latter-Day Saints, described this phenomenon exactly: "We have learned by sad experience that it is the nature and disposition of almost all men, as soon as they get a little authority, as they suppose, they will immediately begin to exercise unrighteous dominion." THE DOCTRINE AND COVENANT OF THE CHURCH OF JESUS CHRIST OF LATTER-DAY SAINTS 121:39 (1839).

159. Allen, supra note 142 .

160. Id. at 261. 
in their historical and social context. For while, in one sense, legal rules exist "out there," constituting shared interpretations of our common legal culture, they are, as well, continually recreated within that culture through interpretation. We cannot begin to understand the processes of law, unless we try to place law in its rich historical and social context. ${ }^{161}$

I have argued that it was Chancellor Allen's willingness as a judge to place legal rules in their broader historical and social context that earned him the right to be called a great judge. He recognized that new developments in business practice do not always mandate new legal rules. The fundamental structure of corporate law has served us well, ${ }^{162}$ and those who would too easily cast it aside are a threat. In years to come, I believe Chancellor Allen will be remembered-with some hyperbole, but nevertheless with a grain of truth-as the judge who saved corporate law. (1993). 